\title{
Capital Markets and Interest Rates in 1970
}

T (t) eraties prices in the World War II have been encountered since early 1970. The markets for both common stocks and bonds staged large rallies between June 1970 and February 1971, after declining in the spring of last year. At their zenith in June, high-grade bond yields reached levels never before recorded in U. S. financial annals. Stock prices slumped to six-year lows in May. Capital market pessimism reached great extremes; some (though not all) observers foresaw a dearth of funds available for investment extending far into the decade. Lower inter" est rates and higher stock prices have doubtless caused revision of such views, although the pace of the market changes makes reappraisal of long-run financing prospects difficult. Beyond that, the 1970 experience raises questions about the causes of such gyrations and their effects on the economy.

\section{Cyclical Variations in Interest Rates and Stock Prices}

Among the unusual features of financial markets in 1970 was the delayed response of long-term interest rates to the business downtum. Whereas in previous postwar business slowdowns, peaks in bond yields occurred promptly after business peaks or even preceded them, three quarters elapsed after the business downturn in 1969 before long-term Treasury and corporate bond yields reached their peaks. Since then, the reductions in yields have been the greatest in amount of any comparable period since World War II. Seasoned corporate Aaa bonds, for example, declined from a peak of 8.6 per cent in the week ending June 26,1970 to 7.1 per cent in the week ending March 5, 1971. Long-term U. S. government securities fell from a yield of 6.8 per cent to 5.9 per cent in the same span of time. In a recent reversal, yields, es-

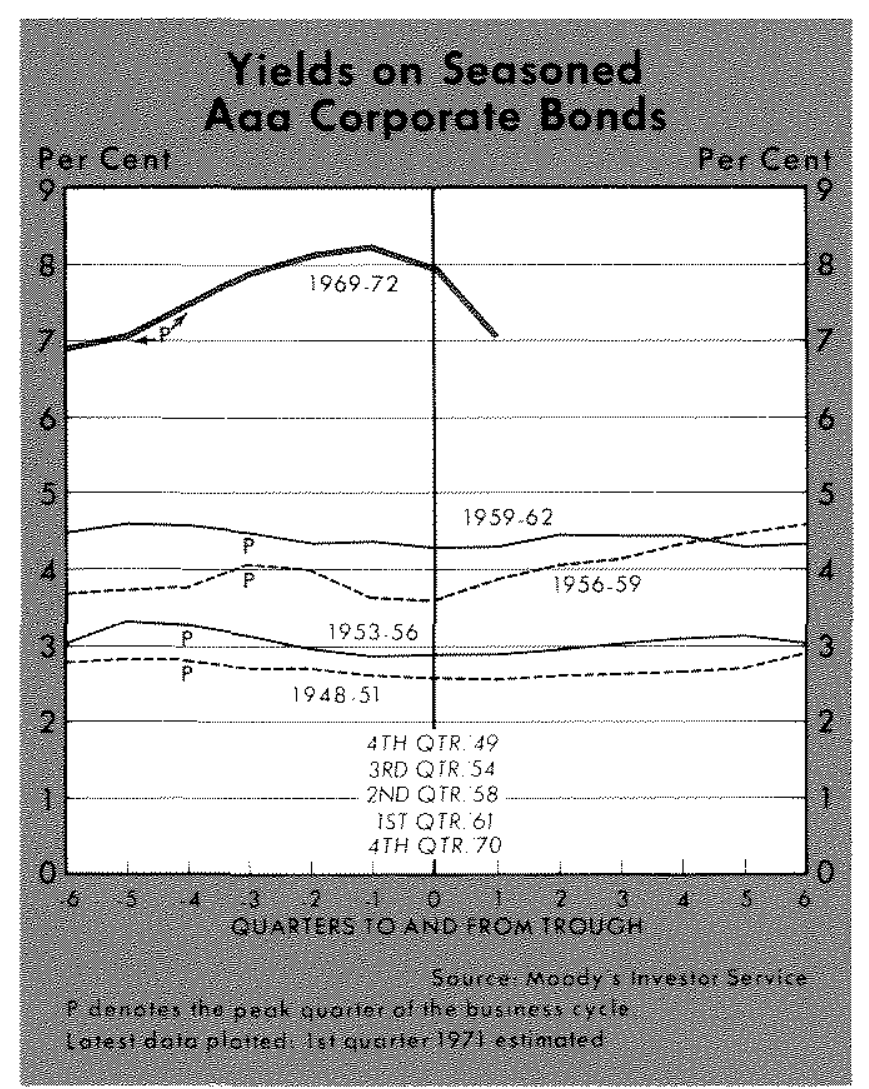

pecially on corporate new issues, have risen and other long-term interest rates have stopped declining.

Short-term interest rates displayed more typical cyclical behavior, reaching highs at the beginning of 1970, a quarter after the downtum in business activity, then falling rapidly with only one temporary reversal throughout the year. The four to six-montl commercial paper rate, which was 9.08 per cent in the second week of January 1970 , plummeted to 4.25 per cent by early March 1971. Three-month U. S. Treasury bill yields fell from 7.91 per cent to 3.35 per cent in the same period. 


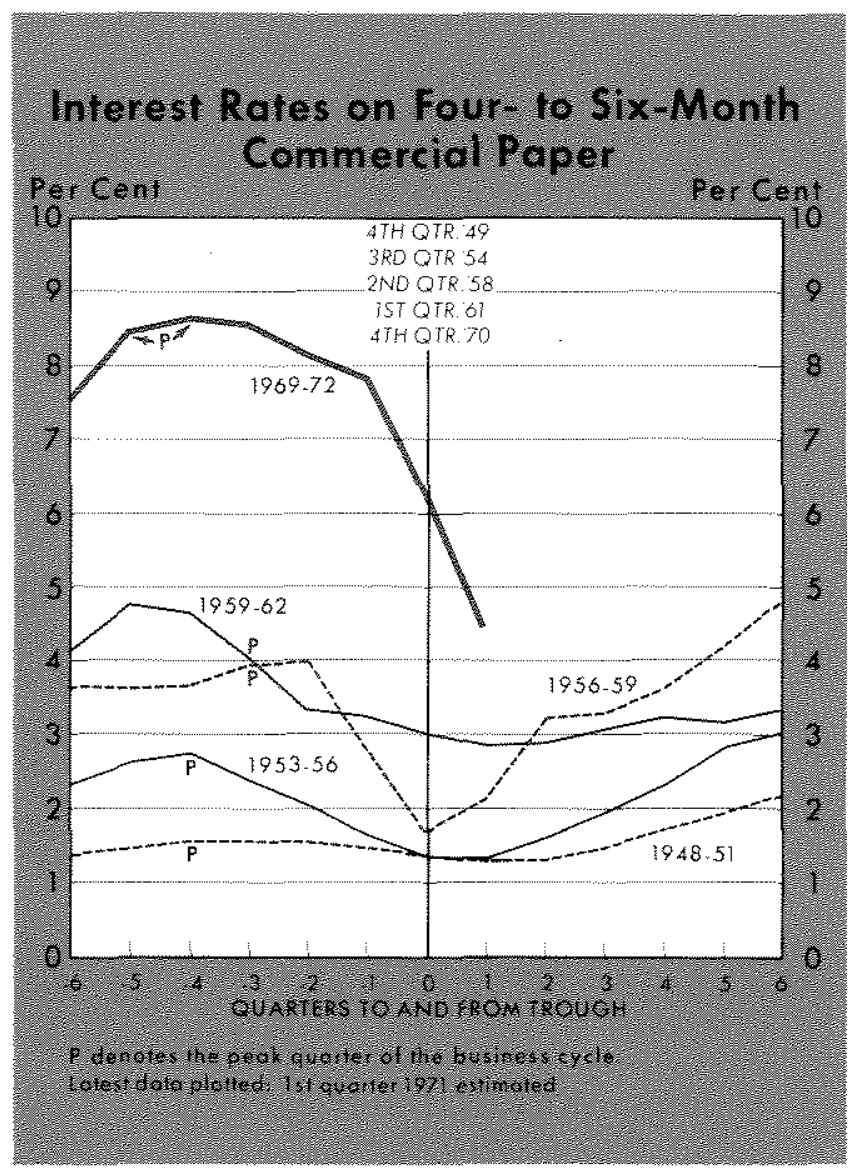

Stock prices underwent a broad retreat throughout 1969 and early 1970. In Spring 1970, retreat threatened to turn into rout for a brief interval, as stock prices fell by 23 per cent between April 1 and May 26. By the end of May, however, the market began to regain composure, and since then, stock prices have rebounded. The Standard and Poor's Index of 500 Stocks $(1941-43=10)$, which reached a low of 69.29 on May 26, 1970, climbed to 97.56 by early March 1971.

\section{Term Structure of Interest Rates}

The accompanying chart depicts three "yield curves" (relationships between maturities of fixed interest-bearing obligations and their market yields) for U. S. obligations with maturities running from less than one year out to thirty years. The curves were observed at three different dates: January 2, 1970 , May 28, 1970, and February 19, 1971. They are based on actual yields on these dates, but each curve has been smoothed to fill in gaps in maturity where no actual obligations are available.

In general, when interest rates undergo a rapid downward readjustment, as in the past fourteen months, both their average level and the term structure of interest rates are affected. It is typical for short-term rates to fall much more rapidly than longtern yields. For example, rates on U. S. Govermment obligations maturing in less than one year, which entered 1970 one percentage point above twenty-year U. S. bonds, were more than two percentage points below long-term bond yields by February 19, 1971. This is consistent with the assmption that the longterm bond yield is an average of a sequence of expected short-term yields. A decline in current shortterm market rates would generally have only a small immediate effect in changing this long-term average.

As mentioned previously, short-term rates peaked several months before long-term rates. If the bond market had anticipated the general decline in interest rates, the decline should have been reflected initially (although mildly) in medium-term or longerterm interest rates. A related development was the whiplash action of the yield curve between January 2, 1970 and May 28, 1970 when yields fell in the shortest maturity ranges, while rising in the mediumand long-maturity segments. Usually, all segments of the yield curve move in the same direction simultaneously, with the short-term end moving more than the long-term end. This pattem did indeed quickly reassert itself by July 1970 .

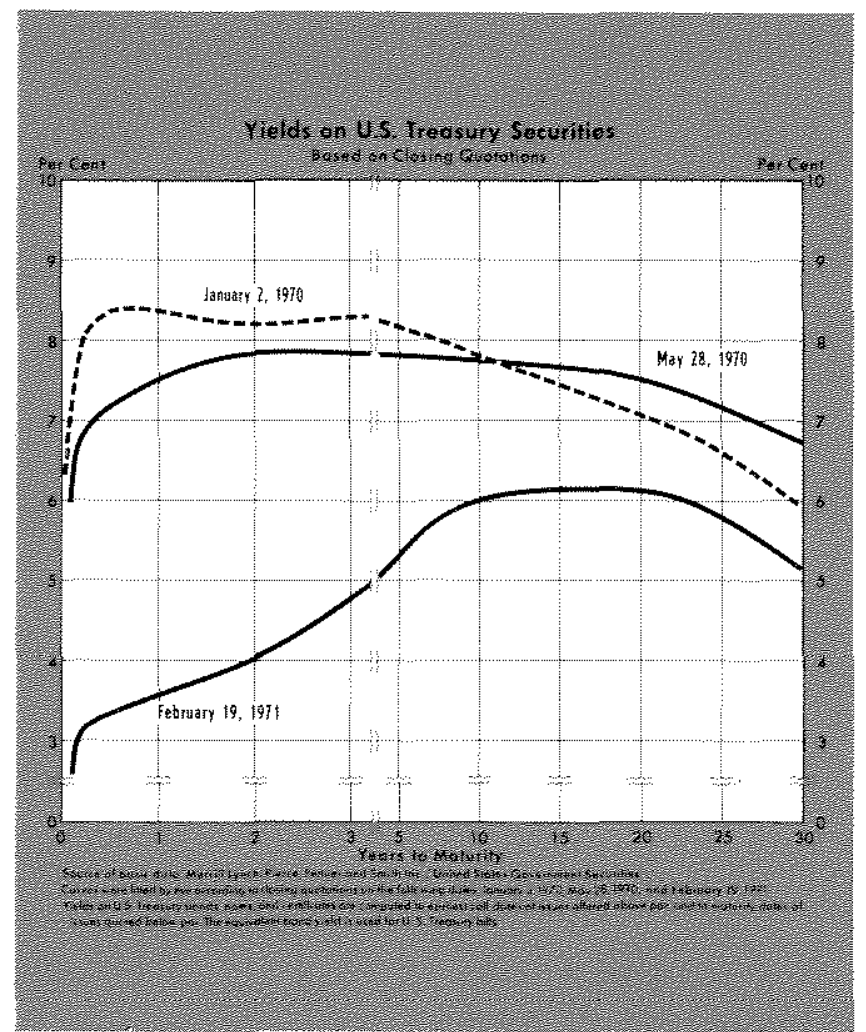




\section{Inflation Expectations and Interest Rates}

The expectations interpretation of the yield curve helps explain how some of the recent change in interest rates was transmitted through the maturity spectrum. Other considerations would explain how the general level of interest rates is detemined. A factor which may have contributed greatly to the high levels of interest rates up to the 1970 peaks is anticipated inflation. Interest rates on new loans were adjusted upward to reflect the expected depreciation of the purchasing power of the dollar during the period of each loan. Since borrowers expect to repay loans in depreciated dollars, they were willing to offer higher interest rates. Lenders, on the other hand, were willing to accept such terms only because high interest rates include an inflation premium that compensates for the expected reduction in the value of the dollar.

In other words, what borrowers and lenders agree upon is a nominal or market interest rate ( $\mathrm{Rn}$ ) which, when the premium for the expected percentage rate of inflation $\left(\Delta \mathrm{P}^{\mathrm{e}}\right)$ is subtracted, leaves a net interest rate (Rr) that represents both an acceptable rate of retum to the lender and cost to the borrower. This net return, after allowing for anticipated inflation, is what some economists have labelled the "real" rate of interest. ${ }^{1}$ That is, the real rate, $\mathrm{Rr}$, equals $\mathrm{Rn}-\Delta \mathrm{Pe}$.

This interpretation of interest rate movements has been incorporated in the interest rate equations of the St. Louis model." It has also been employed in a related study of stock price determination. ${ }^{3}$ These studies find that other factors influence real rates of interest, notably growth in the money stock (currency plus demand deposits) which exercises a short-lived negative effect (positive on stock prices), and growth in real output, which affects the real rate of interest positively with a lag over a longer time span (negative effect on stock prices). Corporate after-tax profits also have a positive impact, with a lag, on stock prices. Anticipated inflation, in the sense already described, has a powerful influence in these equations, tending to drive average stock prices down and interest rates up."

Finterest Rates and Price Level Changes, 1952-69" this Reticw (December 1969), pp. 18-38.

2 "A Monetarist Model for Economic Stabilization," this Review April 1970), pp. 7-25.

"Expectations, Money and the Stock Market," this Review (January 1971), pp. 16-31.

the effect of anticipated inflation on stock prices runs counter to some interpretations of stoeks as "hedges" against inflation. The findings suggest that expected corporate earmings do not fully adjust to anticipated price advances. Investors apparently regard common stocks typically as mixtumes
Most of the rise in bond yields from 1965 until early 1970 can be attributed to the escalation in the inflation prenium. It appears, however, that inflation anticipations (based on past price experience) cannot fully account for the high levels of interest rates (and low levels of stock prices) in the second and third quarters of 1970. Correspondingly, in the first quarter of 1971, the interest rate equations forecast only a mild decline in rates, by comparison with the declines which have already occurred. Stock price forecasts are below the current market average, although the direction of change is being correctly predicted. Either inflation fears are now subsiding more rapidly than these equations recognize, or some other factors are at work pulling interest rates down.

\section{Other Possible Explanations for Recent Interest Rate and Stock Price Movements}

Apart from anticipated inflation, other factors might have exercised an influence on nominal interest rates by altering the real rate of interest. Such factors include special disturbances affecting either the supply of money relative to the demand for money, or the How of intended saving relative to intended investment. In addition, there might have been sudden or unusual shifts among sectors in their borrowing or lending pattems, causing temporary adjustment problems that could have been reflected in interest rates. Recent developments will be surveyed from each of these points of view.

\section{Factors Affecting Demand for and Supply of Money and Near Monies}

Rapid growth in monetary aggregates relative to growth in demand for them should exert downward pressure on interest rates - in the short run. The opposite short-run effect on rates occurs when the supply of monetary aggregates is growing less rapidly than their demand.

Monetary rates of change, both including and excluding net time deposits, reached lows in the latter half of 1969 , and thereafter reversed the downtrends that began in 1968. Business activity began to recede in the third or fourth quarter of 1969. This represents

of fixed nominal income streams, like bonds, and earnings streams that escalate with inflation, For this reason, the average price of all common stocks cannot be viewed simply as the market valuation of real capital.

Net time deposits are total time deposits less large denomination CD's. A similar statement could be made describing the rate of growth in money plus total time deposits, or even broader liquidity aggregates including savings and loan shares and mutual savings bank deposits. 


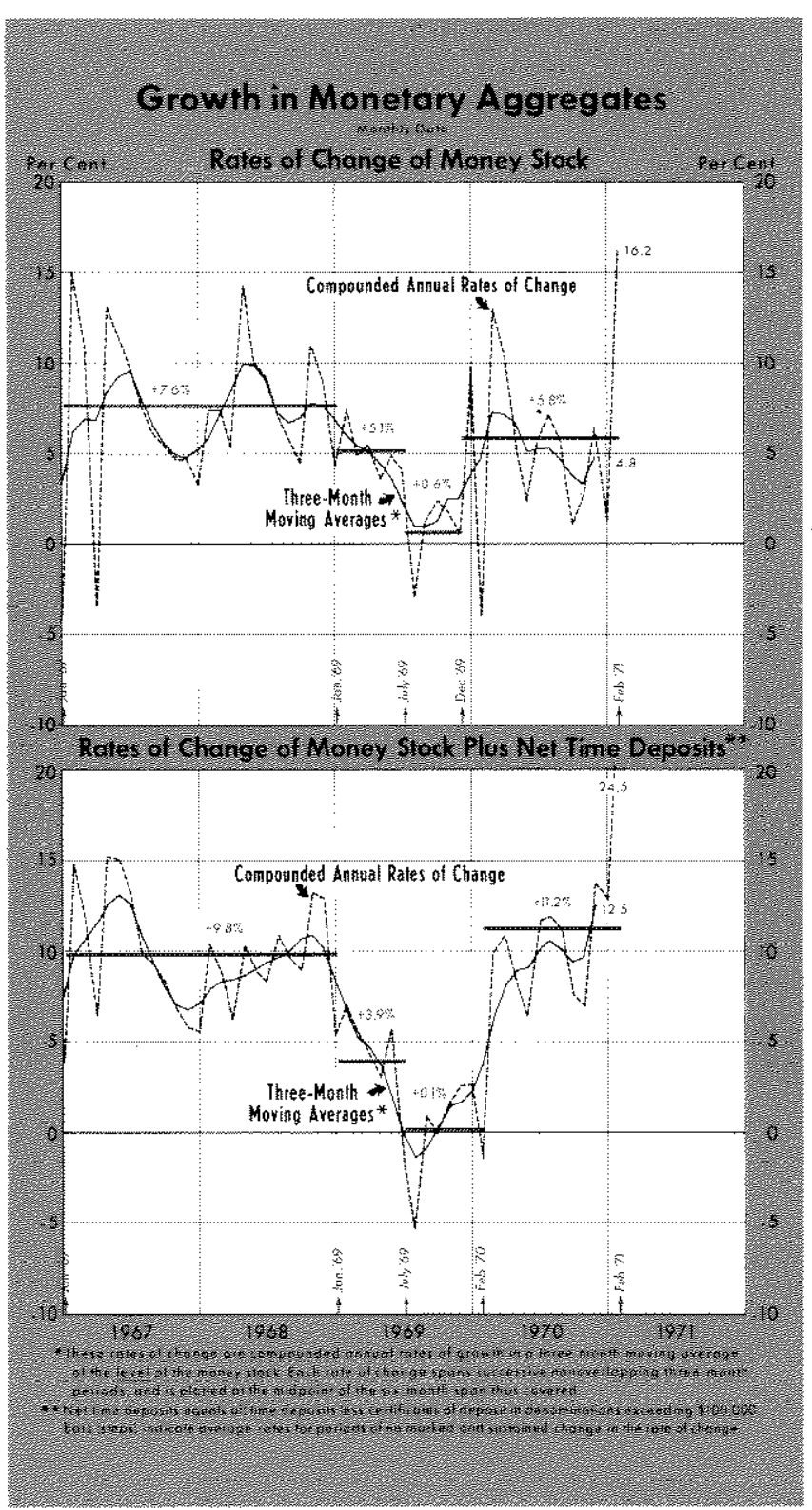

a relatively early turnaround in comparison with monetary rates of change near previous postwar business cycle peaks." Frequently the lowest rates of monetary growth have come several months after the business peak. Hence, the continued high level of interest rates in carly 1970 cannot be attributed to sluggish increases in the monetary aggregates in the face of the business slowdown.

During the last half of 1970 , when interest rates fell sharply, the large increase in negotiable CD's was

Centered rates of change of moving averages give somewhat different results than "step" rates of change. Both are shown in chart above. The "step" method is generally used in this Bank's reports. Changes in "steps" tend to be preceded by peaks and troughs in centered moving average rates of change. a prominent feature of growth in monetary aggregates. Negotiable CD's grew from $\$ 13.2$ billion in June 1970 to $\$ 27$ billion in February 1971. Money supply plus all commercial bank time deposits increased at a 17.4 per cent annual rate in the same period. Upward interest adjustments on CD's (following suspension in June of Regulation $Q$ interest ceilings on large CD's of less than 90 days maturity), combined with a declining trend of interest rates on competitive assets such as commercial paper, Eurodollars, and Treasury bills, made CD's more attractive for businesses to hold.

There has also been a very substantial increase in net time deposits at commercial banks and savings institutions. Between June 1970 and February 1971, these liquid assets grew by $\$ 43.1$ billion. Over the same time span, money supply, defined as currency plus demand deposits, rose at a 5.7 per cent annual rate. In comparison with the turnarounds in previous periods of monetary expansion, the increased growth in the money stock relative to its low point in 1969 has been moderate, but the recovery in growth of money stock plus net time deposits has been rapid.

Some of this growth can be ascribed to "reintermediation" which occurs when interest rates decline on competing liquid assets. In addition, the decline in these interest rates, especially in recent months, has received a significant stimulus from expansionary monetary policy. For example, reserves of member banks have increased at an annual rate of 14.3 per cent since last June. The recent high rates of growth in the broader aggregate of money plus net time deposits reflect both the rapid expansion in bank reserves and the sharp decline in interest rates on marketable securities.

A useful, though crude, measure of the demand for money balances in relation to income is the "income velocity of money" - the ratio of income to money balances. This ratio is an indicator of the turnover rate of money balances in exchange for goods and services. The following chart shows the ratio of GNP to money plus "net time deposits" (commercial bank time deposits excluding large denomination CD's) in postwar business recessions. The amount of money balances demanded increases either more or less than proportionately with income or GNP. During much of the postwar period, the chart shows velocity to have risen with each successive business cycle, indicating a tendency for holders of money and net time deposits to increase their spending on goods and services faster than the growth in their liquid 


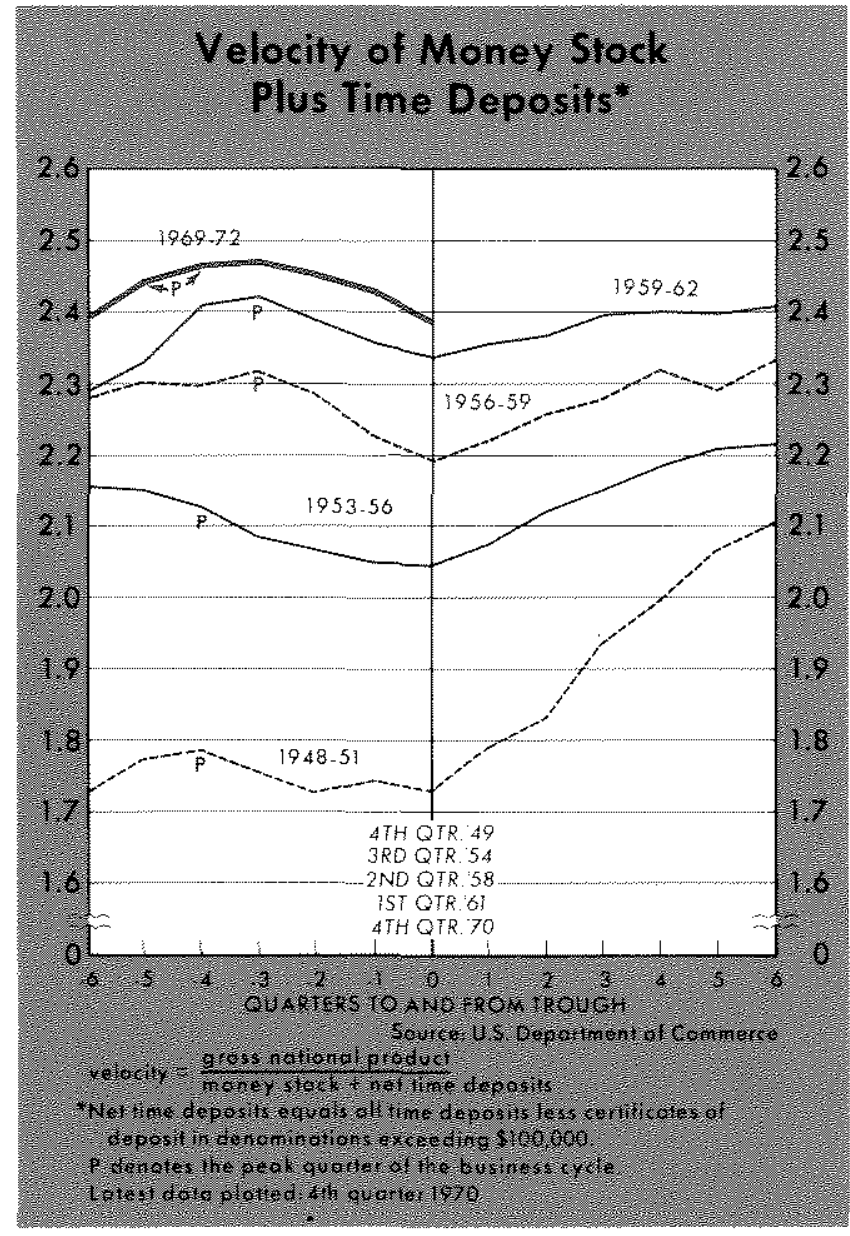

balances. ${ }^{7}$ However, during business slowdowns, velocity falls - monetary assets increase relative to GNP. This happened in each of the recessions of 1949,1954 , 1958, and 1961, and in 1970.

The decline in velocity during business slowdowns is typically associated with reductions in interest rates. ${ }^{8}$ After the business trough is reached, interest rates rise and velocity tends to recover. If the contracyclical rise in long-term interest rates in early 1970 had been the result of a sudden rise in the demand for money plus net time deposits, we should be able to detect it in an abnormally sharp drop in velocity. ${ }^{9}$ Similarly, the rapid decline in interest rates would be associated with an abnomally sharp rise in velocity - signifying a reduction in the demand for money plus net time deposits. The decrease in velocity dur-

TThe rise in velocity of money stock as conventionally defined has been greater than the rise in the velocity of money plus "net time deposits," especially in the last decade.

The rise in velocity between successive post World War II business cycles is associated with (and may, in part, be due to) successive higher levels of interest rates.

Assuming that mintended variations in velocity are of negligible importance. ing the 1970 business contraction was not unusual by comparison with postwar recessions. Nor has there been any evidence of an tmusually sharp rise in velocity in recent months. Except for possibly the fourth quarter, one may rule out sudden changes in the demand for money plus net time deposits as a contributing factor to the abnormal behavior of interest rates since January 1970.10

The velocity of money plus net time deposits is perhaps too broad a measure, especially since it tends to consist very largely of liquid assets held by households, which exhibited none of the symptoms of a liquidity erisis in 1970. Some observers found such symptoms among business firms reacting to unfavorable financial developments in 1970. The failure of Penn Central Company sent liabilities of business failures upward in midyear. Corporate profits sagged for four quarters in a row beginning with third quarter 1969. Liquidity positions of nonfinancial corporations, by a variety of yardsticks, were stretched thinner in mid-1970 than in any previous postwar year. There is little evidence, however, that in 1970 a significant number of otherwise financially viable firms were forced to close tor liquidity reasons alone.

Velocity of nonfinancial corporate cash balances tends to decline during business contractions. The 1970 decline was delayed until three quarters after the fourth quarter 1969 turning point in business activity, but it is not clear whether this was a cause or a result of high interest rates. To be a cause of high interest rates, one must assume the rise in corporate velocity after the business peak was mintended, so that corporations were attempting to improve their liqutidity positions. Much of what appears to be a decline during 1969 and early 1970 in corporate liquidity (rise in velocity) merely represents switching from negotiable CD's to commercial paper and govemment securities. Such shifts were a result of high interest rates (and regulatory interest ceilings on CD's), not a cause of high interest rates.

WThe General Motors strike of September-November, 1970 may have temporarily depressed the amount of money demanded in the fourth quarter of 1970 by reducing output and income below what it wonld have otherwise been. This response would not be fully reflected in velocity, if both income and demand for money declined and inoney stock were also reduced or permitted to grow less rapidly. Interest rates, therefore, conld have been forced downward in the fourth quarter because of the effect of the strike. In the three months since the strike was settled, output growth has recovered from its strike-induced low, but interest rates hive continued to fall. Other factors are evidently at work in redicing interest rates currently. 


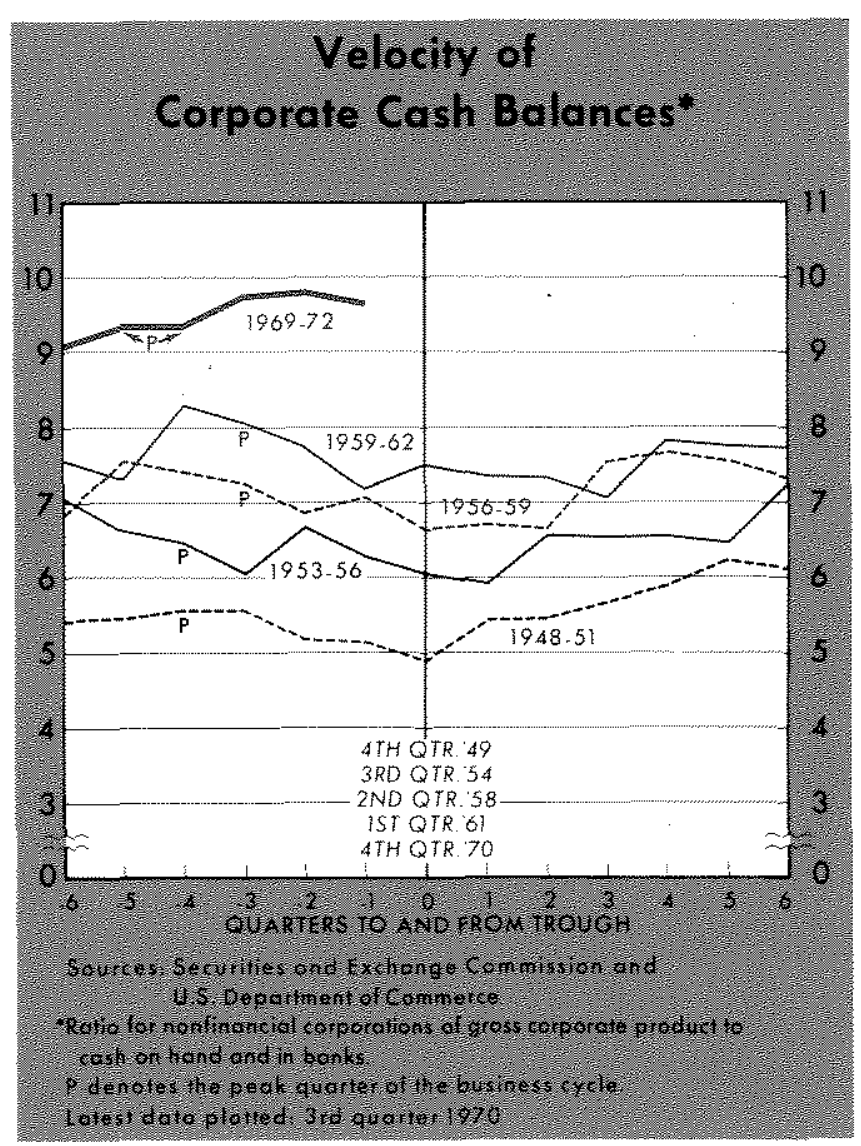

More recently, the velocity of corporate cash balances has declined, partly because of the reversal of previous movements out of CD's. Even so, corporate liquidity is not at present exceptionally high, nor has it improved rapidly by comparison with experience in previous business slow downs. Hence, current downward pressures on interest rates do not appear to have their origin in greater liquidity of corporations.

\section{Saving and Investment in \\ a Business Slowdown}

An excess of intended saving over intended investment tends to reduce interest rates, and conversely. There are practical difficulties, of course, in distinguishing intended from actual saving and investment. One technique for attempting this involves a decomposition of saving by sector and investment by category of expenditure, within the national income accounting framework. Saving is composed of three volatile components - personal saving, corporate undistributed profits (adjusted to remove inventory revaluation), and the net surplus of Federal and state and local governments. Investment consists of residential construction plus business expenditures on durable equipment, and structures, and inventory accumulation, shown in the accompanying chart.
Personal saving, measured in the national income accounts as disposable income minus consumption expenditures, excludes accumulation of consumer durables. It represents mainly liquid asset accumulation, net of additions to consumer debt. During the current business slump, this category of saving grew as a percentage of personal disposable income from 5.3 per cent in the second quarter of 1969 to a peak of 7.6 per cent in the third quarter of 1970 , and declined slightly to 7.3 per cent in the fourth quarter. Taken by itself, the rise in personal saving has exerted a downward influence on interest rates since 1969.

In previous postwar recessions, the personal saving rate has shown no clear cyclical pattern; it has sometimes risen, sometimes declined. The cyclical variation in measured personal income around its expected growth path does not seem to exercise a substantial influence on the saving rate. Part of its behavior may reflect monetary growth itself, since high rates of liquid saving relative to income are likely to take the form of rapid accumulation of cash balances. A rise in price levels will reduce the purchasing power of liquid assets and might induce households to attempt to restore that purchasing power by increased liquid

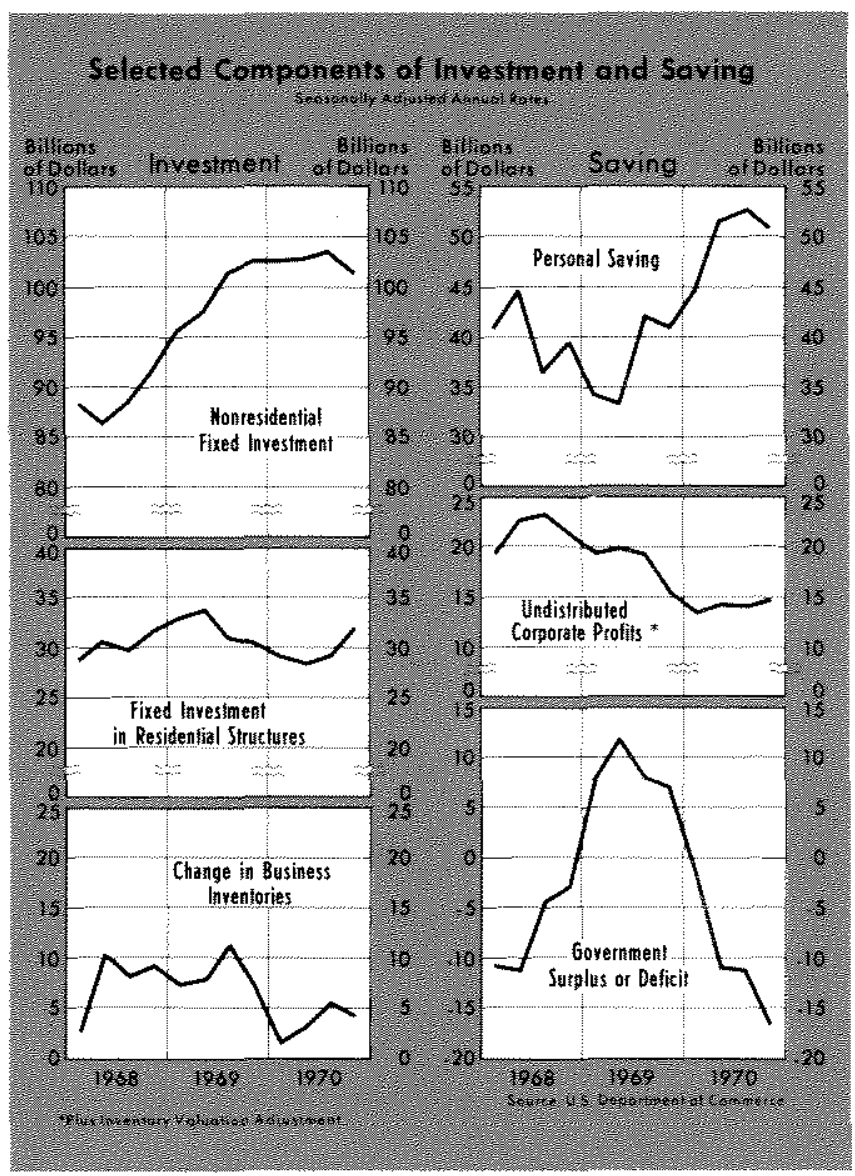


saving. Sustained inflation, on the other hand, builds up anticipation of future price advances, which tends to discourage liquid saving. Higher interest rates on liquid assets, however, could compensate for anticipated inflation, and may have done so to some extent in recent years.

The rise in the personal saving rate that began in the third quarter of 1969 appears to coincide with more rapid monetary growth. Looking ahead, a substantial decline in personal saving rates could occur as a result of lower interest rates, slower monetary growth or reduced inflation, especially if anticipated inflation remains high.

Investment in dwellings is generally regarded as highly responsive to interest rate movements, rather than as a factor operating to exert strong pressure on interest rates, especially pressure of a procyclical nature. High and rising mortgage interest costs in 1969 and early 1970 were reflected in declining residential construction expenditures. Federal govemment support of housing programs may have moderated the decline. Since the second quarter, homebuilding ex. penditures have rebounded to an annual rate of $\$ 32$ billion, less than $\$ 2$ billion below their 1969 peak. Prospects for a continuation of this resurgence have been bolstered by the recent declines in long-term interest rates. These have enabled the Federal govemment to reduce $\mathrm{FHA}$ and $\mathrm{VA}$ ceiling mortgage loan rates to 7 per cent from the $8 \frac{1}{2}$ per cent level of December 1969.

Capital expenditure plans in the business sector were exceedingly bullish in the early stages of the economic slowdown. Initial anticipations called for plant and equipment outlays in 1970 to increase by more than 10 per cent over the previous year. Actual 1970 business capital spending was only 6.6 per cent greater than in 1969. As the chart (p. 7) shows, business spending on equipment and nonresidential structures tumed down after the third quarter of 1970. Nevertheless, the early plant and equipment surveys for 1970 mirrored the upward thrust of fixed iavestment intentions at the outset of the 1969-70 slowdown. Coupled with declining profits, which reduced the ability of comorations to finance capital spending through retained eanings, the net pressure on interest rates of the corporate sector's intended saving and fixed investment was undoubtedly upward in early 1970.11 Capital spending plans were revised

\footnotetext{
IA $\$ 9.7$ billion decline in inventory accumulation from the third quarter of 1969 to the first quarter of 1970 helped offset this pressure. In the second quarter, inventory change reversed direction, and by the fourth guarter was increasing at a $\$ 3.6$ billion annual tate.
}

downward later in the year and corporate profits improved, so that this pressure on interest rates was eased." In the latest survey conducted by the Department of Commerce and $\mathrm{SEC}$ in January and February, business planned to increase its 1971 spending on plant and equipment by 4.3 per cent over the 1970 level.

An important sector affecting capital markets through flows of expenditures relative to receipts is the Federal Govemment. The Federal budget, on a national income accounts (NIA) basis, noved from a surplus at a $\$ 13.4$ billion amnal rate in the second quarter of 1969 to a $\$ 14.2$ billion rate of deficit in the second quarter of 1970 . An increase in the Federal net deficit usually oceurs during business slowdowns due to reduced growth in tax revenues relative to expenditures. Expiration of the surtax, retroactive Federal pay increases, and increased social security benefits also contributed to the decrease in the net surplus in early 1970.

The strong swing by the Federal Govemment from a net "saver" to a net "dissaver" position, primarily between the fourth quarter of 1969 and the second quarter of 1970 , coincides with the abnomally long lag in response of bond yields to a downturn in business activity. A continuing large government deficit may not elevate interest rates, but a rapid increase in the deficit, or decrease in the surplts, may exert temporary upward pressure on interest rates. The decline in long-term interest rates since midyear may therefore represent a return to their typical cyclical response as the Federal deficit passed its period of most rapid increase. ${ }^{13}$

The Federal deficit (national income accounts basis) increased somewhat in the fourth quarter of

\footnotetext{
12 It is conceivable that some or even most of the strength in early capital expenditure plans for 1970 reflected inflation anticipations. Expected productivity of acditional plant and equipment might even have declined throughout 1970. Low and falling levels of capacity utilization suggest that the marginal productivity of new facilities may be decreasing; so also does the deceleration of growth in total real output in the economy, which began in early 1968 . It can be argued that the rate of growth in total output is an approximation to the expected return on physical investment.

13The immediate impact of a sharp rise in the government deficit need not be concentrated in the maturity ranges in which new government debt is being issued. The effects might register most heavily in another sector, if simultaneously with heavy government borrowing in one maturity region, the private sector is retiring debt in that range and increasing its borrowing in some other maturify region. As discussed below, in 1970 corporations were reting their short-term debt while increasing their long-term debt. At the same time the Federal government was borrowing heavily in the short-term end of the maturity range.
} 
1970 to an estimated $\$ 15.3$ billion annual rate. From this point, the NIA deficit is likely to decrease gradually as the economic recovery picks up momentum. The Administration projects a $\$ 15$ billion NIA deficit in fiscal 1971, which would imply deficits averaging more than a $\$ 13$ billion annual rate in the first two quarters in 1971. In fiscal 1972, which begins July 1 , 1971, the NIA deficit is projected to decline to a $\$ 4.2$ billion annual rate. Taking the national income accounts budget as an indicator, and assuming the accuracy of the Administration's projections, the Federal sectors' upward pressure on interest rates would seem to be easing. ${ }^{14}$

\section{Disturbances in the Capital Markets}

Sudden changes in asset and liability positions in various sectors, especially when they are related to alterations in the maturity structure of outstanding credit obligations, sometimes provide clues about the net direction of pressures on interest rates. It is not always easy to distinguish between autonomous and accommodating financial transactions, but when the changes are of extremely large magnitude, as some were in 1970 , there may be less difficulty in disceming the sources of disturbances in credit markets.

Two features of 1970 capital markets are deserving of special mention. The first is the exceptionally sharp increase in long-term borrowing by nonfinancial corporations. Much of this reflected refinancing of shortrun debt (bank loans primarily) carried over from 1969 and earlier, and did not represent a marked change in the rate of growth in total corporate debt. Lengthening of the maturity of corporate debt in 1970 may have eased the pressure of net government borrowing in shortwterm credit markets, while adding to wealness in long-term credit markets early in the year.

The dollar volume of new corporate securities issued (gross proceeds) continued at an unslackened rate throughout 1970 , totaling more than $\$ 38$ billion, only $\$ 8.6$ billion of which were new stock issues. New issues in the first two months of 1971 were in excess of the corresponding months of 1970, and there are as yet no definite signs of a letup in long-term financing demands. The calendar of new corporate issues for March is extremely heavy. Since corporations have been reducing their short-term borrowing, particularly from banks, while adding to their short-term assets,

14 For an evaluation of the Administration's fiscal 1972 budget and 1971 economic plan, see "The 1971 National Economic Plan" in this Review, pp. 11-19. especially CD's, it is evident that many corporations are striving to strengthen their liquidity positions.

The second notable feature was the extremely large rise in commercial banks' net lending, particularly in the third quarter. A major portion of this, of course, arose out of the retirement of commercial paper by banks' parent holding companies and its replacement by CD's. Bank credit expansion was $\$ 25.8$ billion greater (annual rate) in the Summer quarter than in the Spring, after allowing for this. Almost $\$ 15.2$ billion of this increase in bank credit was accounted for by loans to security dealers and brokers to finance acquisition of U. S. Government and other securities. An increase in the rate of acquisition by banks of U. S. Government securities accounted for another $\$ 8.2$ billion (annual rate) of the bank credit increase. Commercial bank lending to business slowed in the third quarter and declined in the fourth. In the fourth quarter, banks became heavy net purchasers of municipal and Federal agency securities.

Long-term bond yields, which had generally declined in January, February, and March 1970, conforming to their cyclical pattern, rose again in April, May, and June. It appears that the sharp declines in the Spring, and the subsequent Summer rallies in bond and stock markets, gained strength from a massive shift in investment policy among securities dealers and brokers, from net liquidation of their positions in the second quarter to aggressive rebuilding in the third quarter. The reasons for this behavior may be traceable to special circumstances - the Cambodian incursion, the campus riots, and a series of failures, forced mergers and recapitalizations among brokerage firms. These events took their toll on the stock and bond markets in the Spring. Then the failure of Penn Central sent tremors through the bond and commercial paper markets in June. After the severe buffeting subsided, securities dealers regained confdence. The much discussed liquidity crisis of the Spring and early Summer of 1970 centered very largely in the fortunes of brokerage firms. It may account for a large part of the unusual cyclical response of bond yields. The effect on interest rates and stock prices, while possibly significant at that time, was short-lived.

\section{Summary and Conclusions}

Interest rates, particularly bond yields, remained near peak levels for an abnormally lengthy period in 1970 after the downturn in business activity. Sev. eral factors could have contributed to this long lag in response. These include (1) the persistence of infla- 
tionary anticipations; (2) the sharp rise in the Federal deficit during fiscal 1970 ; (3) heavy long-term borrowing by corporations, coupled with exuberant capital expenditure programs early in the year; (4) the very gradual decline in real output growth, compared with previous postwar recessions; (5) the financial problems of securities desters, which were reflected in net liquidation of their securities inventory positions in the Spring; and (6) special circumstances, such as the Cambodian incursion and campus rioting. The Penn Central crisis temporarily lifted interest rates in June.

After the mid-year turnaround in bond yields, all interest rates except yields on lower grade bonds went into a decline, which accelerated in the fourth quarter. In part, the fall in rates represented a return to their typical behavior during cyclical downswings in economic activity. The drop in long-term and shortterm rates continued, however, in the first two months of 1971, following the low point of the business slowdown that was reached in the fourth quarter of 1969. In February, three-month Treasury bills yielded less than 4 per cent for the first time since 1967, and Aaa corporate bonds yielded less than 7 per cent for the first time since 1968.

Inasmuch as the high interest rates of the last few years may well have been largely a reflection of inflaw tion anticipations, it is possible that we are now wit. nessing a dramatic de-escalation of these anticipations. A broader interpretation accepts such de-escalation as part of the story. It wotld, however, emphasize other forces exerting downward pressure on interest rates and apward pressure on common stock prices in recent months. These include (1) an improved financial outlook among securities firms; (2) the automobile strike in the fourth quarter; and (3) reduced business optimism regarding rates of return on physical investment (reflected in conservative 1971 plant and equipment spending plans and sluggish short-term business borrowing). An expansive monetary policy, especially as displayed in the broader monetary aggregates, also may have played a major role in the recent bond and stock market rallies.

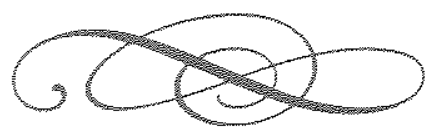

